\title{
Development of LEED Apparatus Using Field-Emission Tips Seigi MIZUNO*1
}

${ }^{* 1}$ Department of Molecular and Material Sciences, Kyushu University, 6-1 Kasuga-koen, Kasuga-shi, Fukuoka 816-8580, Japan

(Received September 29, 2015, Accepted November 15, 2015)

\begin{abstract}
Low-energy electron diffraction (LEED) apparatuses with field-emission (FE) tips were developed. The FE tips were fabricated by field-assisted gas etching to obtain an atomically sharp tip apex. These tips emit single-spot electron beams. Using the FE beams in conjunction with a lensless system, we observed backscattered electrons at the surface of few-layer graphene grown on $\operatorname{SiC}(0001)$. The obtained hexagonal patterns at sample biases of $93 \mathrm{~V}, 54 \mathrm{~V}$, and $28 \mathrm{~V}$ were interpreted as diffraction spots derived from the graphene, the $\mathrm{SiC}(0001)$ substrate, and a buffer layer, respectively. On the basis of the opening angle of $\mathrm{FE}$, the irradiated areas were estimated to be $350 \mathrm{~nm} \phi$ when the sample bias was $100 \mathrm{~V}$. Since the FE beams were easily focused by a magnetic lens, a LEED apparatus with the focused FE beams was also examined. This approach might be useful for improving the sharpness of LEED patterns.
\end{abstract}

\section{1. はじめに}

低速電子回折（LEED）は表面数原子層の逆格子を歪なく 得ることができる表面敏感な手法として広く利用されてい る. また, 電子線のエネルギーに対する回折強度の变化を測 定して, 多重散乱を考慮に入れた動力学的回折理論を用いて 解析することにより, 単位格子中の原子の座標を $0.1 \AA$ 程度 の精度で決定できるという優れた特徵を持っている. 一方 で, 通常の LEED 装置の電子線の直径は $0.1 \sim 1 \mathrm{~mm}$ 程度と 大きく, 平均的な情報を得ることになる. 表面微小領域を低 速電子線でプローブするためには工夫が必要であり, 低速電 子顕微鏡においては, 試料に電子線が入射する直前に急減速 させることによって高い空間分解能を達成している. 一方, Spot profile analyzing (SPA)-LEED は，2 段 8 極子偏向コ イルとチャンネルトロン検出器を用いて, 高い逆空間分解能 を達成している，筆者らは，低速電子顕微鏡や SPA-LEED とは別の方法で表面微小領域をプローブする手法, 抢よび, 複雑な表面構造を解析するための装置の開発を進めてきたの で，その現状を報告する。

\section{2. 電界放出電子源}

電界放出電子線はエネルギーの広がりが小さく, 点光源と することが可能なために収束させやすく, コヒーレントな電 子線源として魅力的である. 現在市販されている電界放射型 電子顕微鏡においては, $5 \mathrm{kV}$ 程度の引出電圧を用い, スリ ットとレンズを用いて電子線を収束させている。これに対し て, 筆者らは, 低い引出電圧を用い, あまり加減速せずに利 用する方法を試みてきた.

\section{1 電界誘起ガスエッチングによる針の先鋭化}

このため, 電界誘起ガスエッチング法により針先端の先鋭 化を試みた。この手法は最初に Rezeq らによって窒素を用 いた先鋭化法として見出された1). タングステン針のヘリウ

* e-J. Surf. Sci. Nanotech., 10 (2012) 292. で主な部分発表

*1 九州大学総合理工学府物質理工学専攻（干816-8580 福岡県春 日市春日公園 6-1)
ムを用いた電界イオン顕微鏡像観察中に，窒素を導入する と, 窒素が針先端周辺部に吸着する.この際, ヘリウムで原 子像が見えている針先端の領域は電界が高いため, 窒素は吸 着できない。一方, 針周辺部に吸着した窒素はタングステン と小さな突起を形成し，局所的に電界が高くなって電界蒸発 を引き起こす（その意味ではガス吸着誘起電界蒸発の方が適 した表現である)。その際，針先端のタングステン原子が電 界蒸発しないように少しずつバイアスを下げながらエッチン グを進めると，円錐状に針先端を先鋭化することができる.

筆者らは酸素や水でも同様に先鋭化できることを見出し，そ の評価を行った ${ }^{2)}$. Fig. 1に〈111〉を向いた単結晶タングス テン針の電界イオン顕微鏡像と, 酸素を用いたエッチングに よる変化を示す．エッチングの進行に伴い，針先端の曲率半 径が小さくなり，拡大率が増大している。初めに $4.4 \mathrm{kV}$ 必
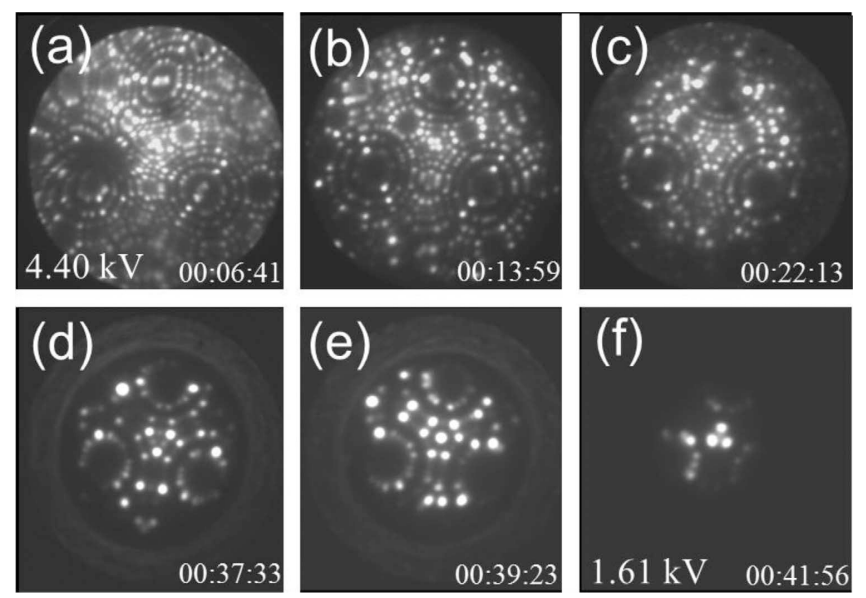

Fig. 1 FIM images observed during and after the field-assisted $\mathrm{O}_{2}$ etching of a $\mathrm{W}\langle 111\rangle$ tip. (a) FIM image of a hemispherical single-crystal $\mathrm{W}\langle 111\rangle$ tip prepared from an electrochemically etched tip by field evaporation at potentials up to $4.4 \mathrm{kV}$. (b)-(f) FIM images captured from a real-time movie during the $\mathrm{O}_{2}$ etching reaction. The bias voltage was reduced from $4.4 \mathrm{kV}$ to $1.6 \mathrm{kV}$. The $\mathrm{O}_{2}$ gas was gradually shut off from (d) to (f). 

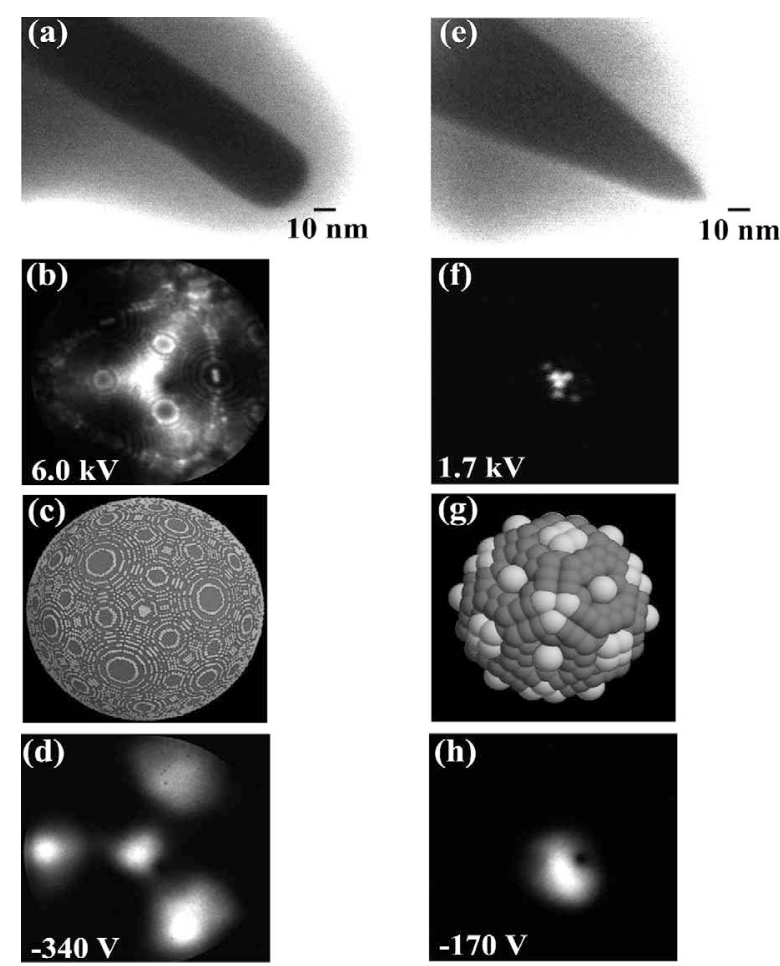

Fig. 2 (a)-(d) STEM images, FIM images, corresponding ball models, and FEM images of the tip before field-assisted $\mathrm{O}_{2}$ etching. (e)-(h) Those after field-assisted $\mathrm{O}_{2}$ etching.

要だったバイアスをFig. 1(f)では $1.6 \mathrm{kV}$ まで下げており, 先鋭化したことがわかる. また，先端の 3 個のタングステ ン原子が際立って明るく見えている．この状態は安定で，へ リウムイオンビーム源としても利用されている.

先鋭化前後の針の形状と電界放出の比較を Fig. 2 に示 す3). Fig. 2 (a)はく111〉を向いた単結晶タングステン針（直 径 $0.25 \mathrm{~mm}$ ）を $2 \mathrm{~N}$ 水酸化ナトリウム溶液中, 白金環状電極 を用いて直流電流による電解研磨により溶断し, 電界イオン 顕微鏡で電界蒸発により針先を清浄化した後の電子顕微鏡像 である. 針先端は曲率半径数十ナノメートルの半球状であ る.この針を電界誘起酸素エッチングで先鋭化した後の電子 顕微鏡像が Fig. 2 (e)である. 針先端が円錐状に尖っている 様子がわかる. Fig. 2(b)，(f) は電界イオン顕微鏡像，(c), （g）はボール模型である. また，Fig. 2(d)，(h) はそれぞれ の針からの電界放出電子線の形状である. 先鋭化前は〈111 $>$ 以外に 3 つの $\langle 114\rangle$ 方位にも電界放出が見られるが, 先鋭化 後は〈111〉のみからの電界放出となっている. 畑らは同様の 方法で先鋭化した針先端の透過電子顕微鏡像により, 針先端 に形成した小突起の結晶格子を観察している4 ${ }^{4}$.

\section{2 電子線源用の電界誘起ガスエッチング}

針先端をできるだけ尖らせるためには, 先端のタングステ ン原子が電界蒸発しないようにバイアスを下げながら電界誘 起ガスエッチングを行うとよい，このような針は，走査トン ネル顕微鏡や原子間力顕微鏡の探針として有用と思われる. 一方で, できるだけ広がり角の小さな電界放出電子線をとり 出すためには, 比較的曲率半径の大きな針先端に小さな鋭い 突起をもつ構造を作るのがよい，このような針先を得るため には, バイアスを固定して, 針先端のタングステン原子を電
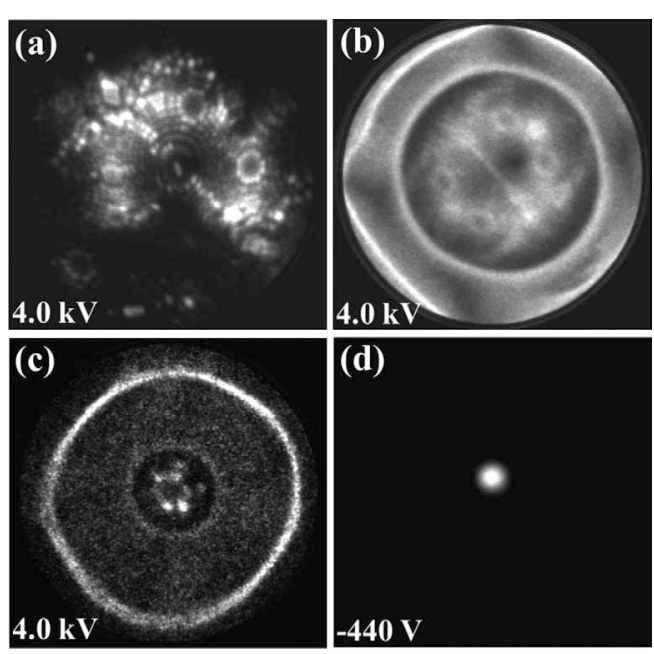

Fig. 3 Fabrication of a nanotip. (a)-(c) FIM images during field-assisted $\mathrm{H}_{2} \mathrm{O}$ etching. The bias voltage was fixed at 4.0 $\mathrm{kV}$. (d) FEM image after stabilizing the tip apex by the fieldenhanced diffusion-growth [Appl. Surf. Sci., 182 (2001) 12] method.

界蒸発させながらエッチングを進め, 最後に数原子のタング ステンを残す5). Fig. 3 にその様子を示す．大量のタングス テン原子をエッチングする必要があるため, エッチング速度 の速い水を用い, 室温で行った. また, 〈111〉を向いた単結 晶タングステンワイヤーは高価なため, 通常の多結晶タング ステンワイヤー（ほとんどがく $110 〉$ 方位を向く）を用いた.

Fig. $3(\mathrm{~b})$ はエッチング中の電界イオン顕微鏡像で, 中央の $\mathrm{W}(110)$ の結晶構造が見えている部分はへリウムによる結像 であり, その外側の領域は水による結像である. 外側の領域 がエッチングされていき, 最終的に Fig. 3(c)のようにへリ ウムで結像された針先端部に数原子のタングステンが残され た状態にすることができた．この針からの電界放出電子線の 形状を Fig. 3(d)に示す. 針先端数原子からの電界放出であ ると考えられる。W(110)面は広いテラスになりやすく, 仕 事関数も大きいため, 通常は $\langle 110\rangle$ 方位への電界放出は起き にくいが，電界誘起ガスエッチングで先鋭化することによ り，〈110〉方位のみへの電界放出が可能となった。広がり角 は半值全幅で $5^{\circ}$ 程度である．安定にとり出すことのできる 電流は最大数十ナノアンペアで, それ以上の電流をとり出す と壊れてしまう。

\section{3. 微小領域のプローブ}

電界放出電子線をレンズを用いずに利用した微小領域プ ローブ法の研究例について紹介する，また，筆者らは，得ら れた電子源を用いた微小領域プローブ LEED 装置の開発を 試みたので紹介する.

\section{1 電界放出電子線を用いた微小領域プローブ法}

通常の走査トンネル顕微鏡の動作領域からトンネル電流を 一定に保ってバイアスを上昇させていくと（針側に負の電 位), 電界放出の領域となって, 針から試料表面に電子線を 照射させることができる，このとき，針から試料表面までの 距離が近ければ（たとえば $1 \mu \mathrm{m}$ 以下）電子線は試料表面の 
狭い領域にのみ照射されることになる。もし，試料表面で散 乱した電子を観察することができれば, 試料表面微小領域の 構造情報を得ることができるはずである.

このように針からの電界放出電子線をレンズを用いずにそ のまま試料表面に照射する方法には次のような研究例がある.

Young らは 2 次電子を検出しながら電界放出電子線を走査 する topografiner を提案した6,7).この手法は最近, Kirkら により near field-emission SEM とも呼ばれ，W (110)表面 のステップの観察などが報告されており，2 $\mathrm{nm}$ 程度の空間 分解能が得られている8,9). Reihl らは 2 次電子のエネルギー 分析を行い, 走査オージェ電子顕微鏡として用いることがで きることを示している10). ただし，目的のオージェ電子を 得るために 1 次電子線のエネルギーを上げ, 同時に電流を 一定に保つと, 電子源から試料までの距離が指数関数的に長 くなってしまい, 空間分解能が悪くなるという欠点がある. 一方, Fink らは透過型の projection microscope を開発し た ${ }^{11,12)}$.これは電界放出電子線を薄膜や網状の試料に照射 し, 透過した電子線を拡大投影するもので, 電子源と試料, および, 試料とスクリーンの距離の比で拡大率が決まり, カーボンナノチューブなどの観察が可能である.さらに最近 Fink らは，マイクロレンズを用いた回折パターンの測定と 組み合わせて解析を行うことにより, グラフェンシートの広 い領域にわたって $2 \AA の$ 分解能で鮮明な画像を得ることに 成功している13).

\section{2 微小領域からの反射回折パターンの検出}

このようなレンズを用いない方式で試料後方へ散乱した電 子による回折パターンを得るためには, 電子源と試料の狭い 空間から, 弾性散乱電子をできるだけ歪まないようにとり出 すことが必要である，そこで，Fig. 4 に示す走査トンネル 顕微鏡（STM）をべースとした装置を設計・製作して実験 を行った ${ }^{14)}$. 試料表面に対して電子線が垂直入射となるよ うに，電子源の針を配置した。試料側に粗動用とSTM 用の アクチュエーターが備わっており, 通常の STM の測定も可 能である. バイアスは試料側に印加する方式で, + $+100 \mathrm{~V}$ ま で印加可能であり, 電流は $0.2 \mathrm{nA}$ 程度に保って実験を行っ た. 試料表面で後方散乱された電子線は, そのままでは針と 試料の間の電場によって試料側へ引き戻されてしまう。この
ため, 針ホルダーには針からの電場の影響をできるだけ抑え るようにシールド（shield 1) を取り付けてある. また，外 部の電場の影響を抑えるために可動式シールド（ shield 2) も取り付けてあり, 両者に適切なバイアスを印加して, 後方 散乱電子をスクリーン側へ導いている. スクリーンの前には 非弾性散乱電子を取り除くためのグリッドと 2 段のマイク ロチャンネルプレートが設置されている. スクリーン等の中 心に針ホルダー用の穴があり, 針を中心に円筒対称の構造と なっている．針ホルダーを支持する 3 本の脚はスクリーン の後方にあるため, 影にはなるが電場には影響を与えない. また, 地磁気を遮蔽するための磁気シールドで全体を覆い, 下部には冷却用の液体窒素タンクを備えている.

電子源となる針は, 直径 $0.2 \mathrm{~mm}$ のタングステンワイヤー を電解溶断し, 真空中に導入して前述した電界誘起水エッチ ングによって先鋭化した. 試料は $\mathrm{SiC}(0001)$ 表面を真空中で 加熱して数層グラフェンを形成させたものを用いた. Fig. 4 に示した装置で得られた, 数層グラフェンによる電界放出電 子線の散乱パターンを Fig. 5(a)-(c) に示す.この表面の通 常の LEED 装置による回折パターンは Fig. 5 (d)である.
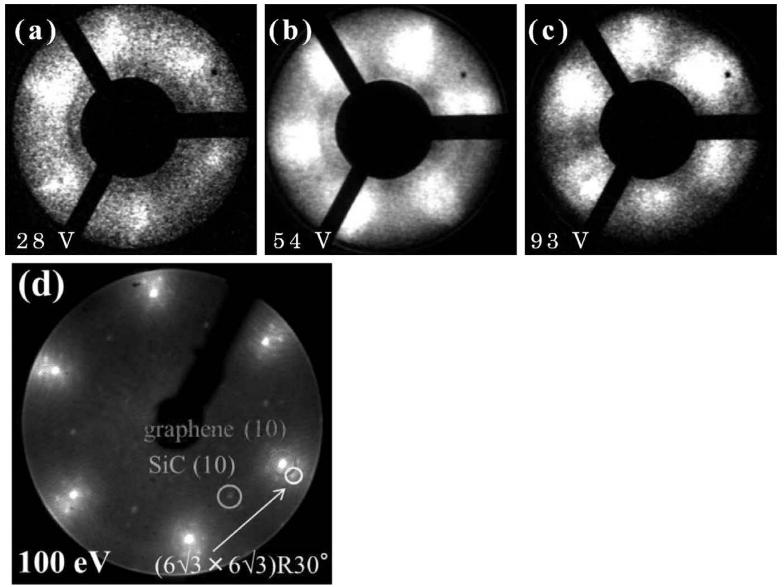

Fig. 5 (a)-(c) FE-LEED patterns obtained and (d) the conventional LEED pattern of graphene on $\mathrm{SiC}(0001)$. (1 0 ) spots from the graphene, $\mathrm{SiC}(0001)$ substrate and the $(6 \sqrt{3} \times$ $6 \sqrt{3}) \mathrm{R} 30^{\circ}$ buffer layer are represented by circles.

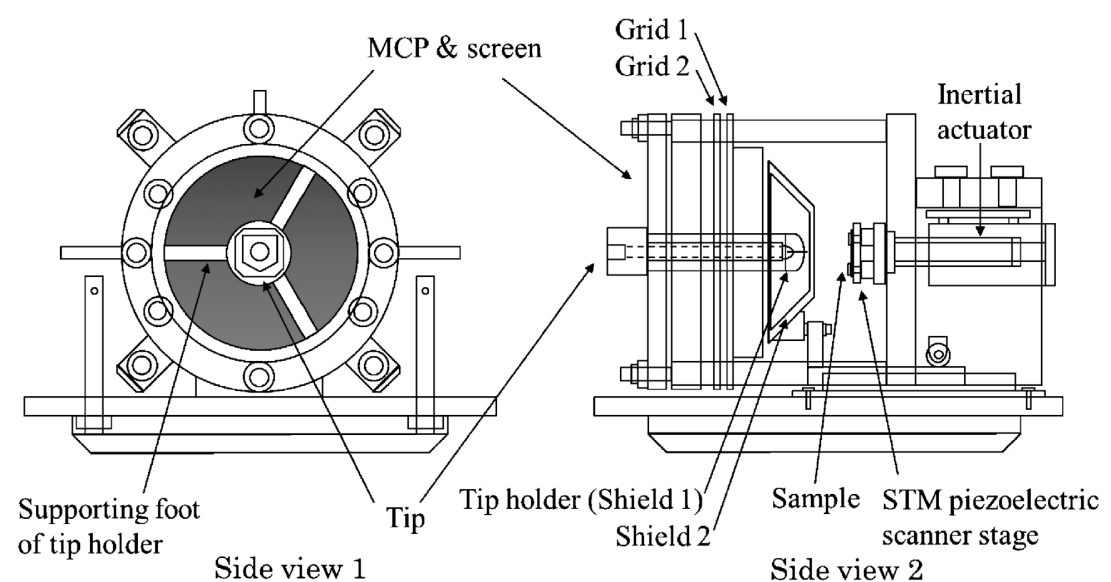

Fig. 4 Schematics of the FE-LEED apparatus. 


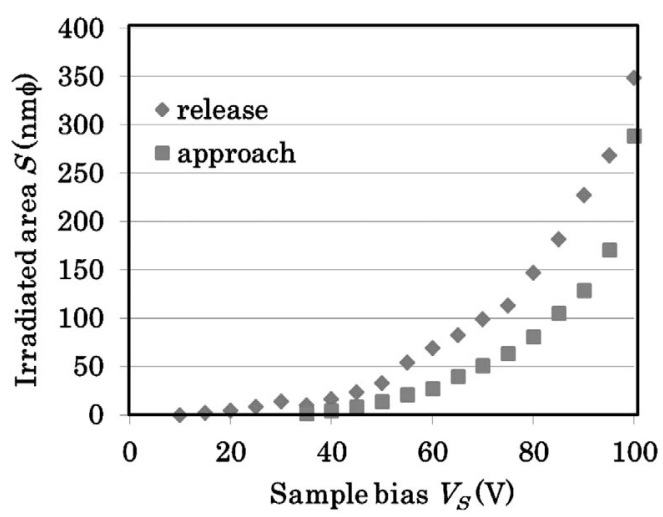

Fig. 6 Estimation of the area irradiated under constant-current mode $(0.25 \mathrm{nA})$.

試料バイアスが $28,93 \mathrm{~V}$ のときは, 通常の LEED パターン のグラフェン（１０）スポットと同じ方向に６回回転対称の 散乱パターンが観察された。これに対して, 試料バイアスが $54 \mathrm{~V}$ の時は30度回転した方向に散乱パターンが観察され た。これら以外の方向へ回転した散乱パターンは観察されな かった．装置は針を中心とした円筒対称であるため，方位角 方向には散乱パターンの歪みは生じない，一方，極角方向は shield 1, 2 などの引出電極の印加電位により変化する. Fig. 6 は針一試料間バイアスと, 針-試料間距離から見積もったプ ローブ径の関係である. バイアス $100 \mathrm{~V}$ のときのプローブ径 が数 $100 \mathrm{~nm}$ であり, 十分狭い領域を測定していると考えら れる.

Fig. 5(a)から(b)，および，(b)から(c)への変化が，磁場 の影響であるとすれば，電子線のエネルギーに依存して徐々 に回転していく様子が見えるはずである.しかし, 途中の回 転角度のパターンは見えず，(a)と（b)あるいは (b) と (c)が 混ざっているように見えるバイアスもあることから, 磁場の 影響ではないことが確認できる. 現時点で, 回折パターンが 見えていると仮定して説明すると，(c) はグラフェンの (1 0), (b)は $\mathrm{SiC}(0001) の （ 10)$, (a) はグラフェンバッフ ァー層の構造に由来するスポットとするのが妥当であろう. しかし， 2 次電子のパターンを見ている可能性なども捨てき れない，また，低バイアス側ではプローブ領域が非常に狭く なることが期待できるので, ラウエ関数が関わっている可能 性もある. 回折パターンであることを明確に示すためには, 電子線の広がりをさらに小さくする工夫が必要である. 今後, Fink らが透過型の回折パターンの測定に用いているような マイクロレンズを用いることや，磁場レンズを用いることを 検討している.

\section{4. 複雑な表面構造解析のための装置}

前章で試料表面として用いた $\operatorname{SiC}(0001)$ 表面上のグラフェ ンバッファー層は $(6 \sqrt{3} \times 6 \sqrt{3})$ R $30^{\circ}$ という大きな単位格子 を持つ. 同様に, $\mathrm{Cu}(111)$ 表面上の単層グラフェンでも (14 $\times 14 ）$ という長周期構造がみられている15). Fig. 7 (a)は $\mathrm{Ag}$ (111) 上のシリコン吸着（620 K ) の LEED パターンで, 弱いスポットが多数観察できる.これらは多重散乱として解 釈することが可能で，周期は $(\sqrt{133} \times \sqrt{133}) \mathrm{R} 4.3^{\circ}$ である ${ }^{16)}$.
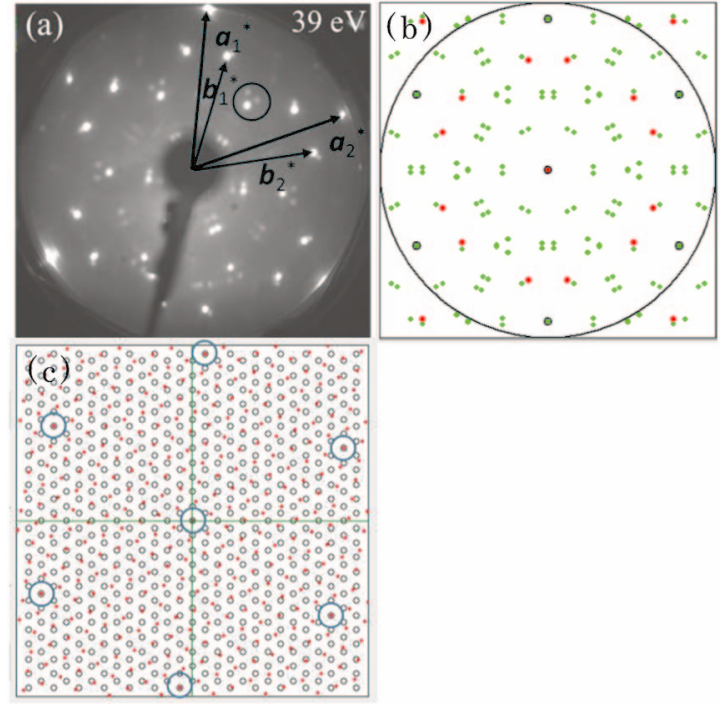

Fig. 7 (a) Typical LEED pattern of the high-temperature phase of $\mathrm{Ag}(111)-\mathrm{Si}$. (b) Simulated LEED patterns for $(\sqrt{133} \times \sqrt{133})$ R4.3 ${ }^{\circ}$. (c) Substrate and overlayer lattices obtained from the simulated LEED pattern.
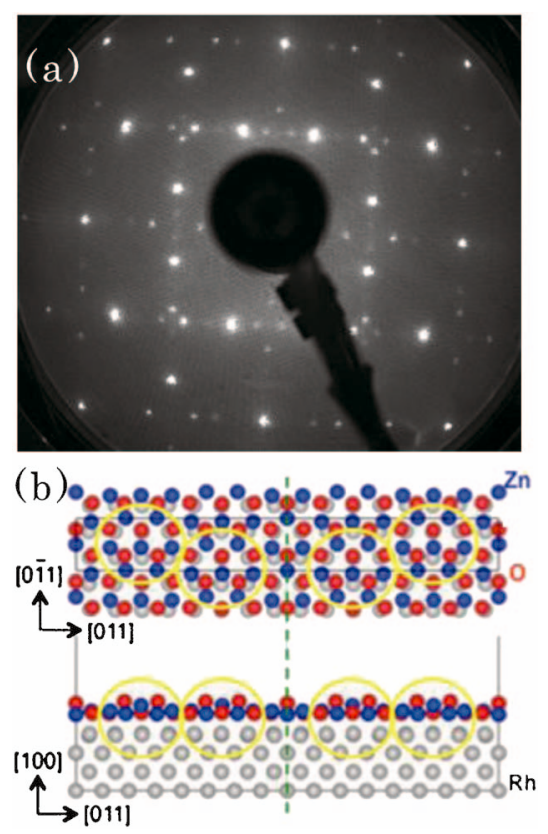

Fig. 8 (a) LEED pattern of zinc oxide film on $\mathrm{Rh}(100)$, as recorded at an incident energy of $82 \mathrm{eV}$. (b) Top and side views of the optimized model A determined by ab initio calculations and quantitative LEED.

これらのような長周期構造の単位格子を決定するには SPALEED が威力を発揮することは間違いない。しかし，それ らの構造を決定するためには, 垂直入射の条件で迅速なスポ ット強度一電子線エネルギー変化（いわゆる $\mathrm{I}-\mathrm{V}$ 曲線）の測 定が必要である. Fig. 8 は $\mathrm{Rh}(100)$ 面上の $\mathrm{ZnO}$ 膜による $(16 \times 2)$ 構造の LEED パターンと, 解析で得られた構造モデ ルである. 一方向についてであるが16倍という長周期の構 造の解析に成功している17). しかし, 二方向について周期 が長くなると， I-V 曲線の測定はますます困難となる．その ため, 従来型の LEED 装置よりも, さらにシャープな回折 


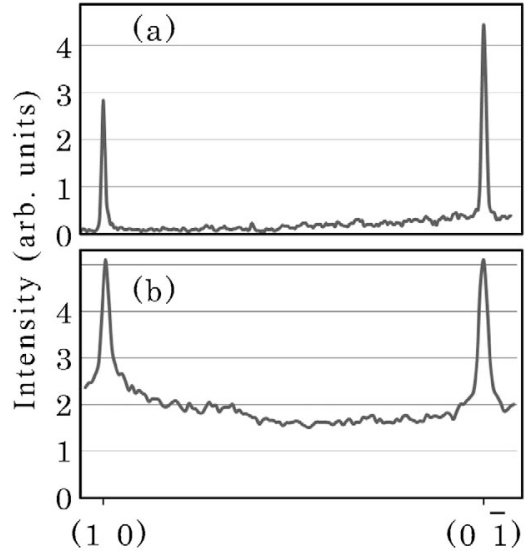

Fig. 9 LEED intensity profiles between $\left(\begin{array}{ll}1 & 0\end{array}\right)$ and $\left(\begin{array}{ll}0 & \overline{1}\end{array}\right)$ spots of few-layer graphene on an $\mathrm{SiC}(0001)$ surface using (a) FE-LEED and (b) conventional LEED at $230 \mathrm{eV}$.

パターンを観察できる装置の開発が望まれる，そこで，筆者 らは，電界放出電子線を磁場レンズで収束させる電子銃を用 いた LEED 装置の開発を試みている.

前述した電界誘起ガスエッチング法で先鋭化した針から は，低いバイアスで電子放出が可能なため, 磁場レンズで容 易に収束させることができる。まだ試作段階であるが，この 電子銃を用いて $\mathrm{SiC}(0001)$ 上の数層グラフェンからの回折パ ターンの（1 $0 ）$ スポットと（０１） スポット間の回折強度 プロファイルを測定した結果をFig. 9 (a) に示す.同じ試料 の通常の LEED 装置によるプロファイル Fig. 9(b) と比べ て, ピークの半值幅が半分程度になっていることを確認する ことができた. 今後, 本格的な装置を製作して回折パターン の測定を進める予定である.

\section{5. 今後の展望}

従来の LEED 装置を用いた構造解析においても，まだま だやるべきこと（構造が未解決のケース）が多数残っている ので，これからも LEEDによる構造解析が盛んになってい くことを期待している. また，針の先鋭化や電界放出電子線
の利用は, 大がかりな装置は不要で, 研究室レベルで比較的 容易に実験できるので, 走査プローブ顕微鏡の探針や電子源 としての利用への取り組みが広がることを期待している.

\section{謝辞}

本稿で紹介した研究の一部は, 科学技術振興機構 ASTEP および科学研究費補助金15H03677の支援を受けたも のであり，ここに謝意を表します。

\section{〔文献〕}

1) M. Rezeq, J. Pitters and R. Wolkow: J. Chem. Phys., 124 (2006) 204716.

2) F. Rahman, J. Onoda, K. Imaizumi and S. Mizuno: Surf. Sci., 602 (2008) 2128

3) J. Onoda, S. Mizuno and H. Ago: Surf. Sci., 604 (2010) 1094.

4) Y. Sugiura, H. Liu, T. Iwata, S. Nagai, K. Kajiwara, K. Asaka, Y. Saito and K. Hata: e-J. Surf. Sci. Nanotechnol., 9 (2011) 344

5) J. Onoda, T. Kanaoka, M. Kumon and S. Mizuno: e-J. Surf. Sci. Nanotechnol., 10 (2012) 292.

6) R. Young, J. Word and F. Scire: Phys. Rev. Lett., 27 (1971) 922.

7) R. Young, J. Word and F. Scire: Rev. Sci. Instrum., 43 (1972) 999.

8) T. L. Kirk, L. G. De Pietro, D. Pescia and U. Ramsperger: Ultramicroscopy, 109 (2009) 463.

9) T. L. Kirk, O. Scholder, L. G. De Pietro, U. Ramsperger and D. Pescia: Appl. Phys. Lett., 94 (2009) 153502.

10) B. Reihl and J. K. Gimzewski: Surf. Sci., 189/190 (1987) 36.

11) H. -W. Fink, W. Stocker and H. Schimid: Phys. Rev. Lett., 65 (1990) 1204.

12) M. Germann, T. Latychevskaia, C. Escher and H. -W. Fink: Phys. Rev. Lett., 104 (2010) 095501.

13) J. -N. Longchamp, T. Latychevskaia, C. Escher and H. -W. Fink: Phys. Rev. Lett., 110 (2013) 255501.

14) J. Onoda, T. Knaoka, M. Kumon and S. Mizuno: e-J. Surf. Sci. Nanotech., 10 (2012) 292.

15) H. Ago, Y. Ohta, H. Hibino, D. Yoshimura, R. Takizawa, Y. Uchida, M. Tsuji, T. Okajima, H. Mitani and S. Mizuno: Chem. Mater., 27 (2015) 5377.

16) Md. S. Rahman, T. Nakagawa and S. Mizuno: Jpn. J. Appl Phys., 54 (2015) 015502.

17) J. Yuhara, D. Kato, T. Matsui and S. Mizuno: J. Chem. Phys., 143 (2015) 174701. 